\title{
HAEYNA BODNAR
}

(iD https://orcid.org/0000-0002-7972-8111

Lwowski Uniwersytet Narodowy im. Iwana Franki

\section{Wojna w jednym losie}

Narracje biograficzne wdów sowieckich wojskowych

na przyßładzie listów do władz Lwowa z lat 1944-1945

W latach 1939-1941 oraz od lipca 1944 r. wraz z nadejściem Armii Czerwonej Lwów był zasiedlany przez sowieckich urzędników, pracowników aparatu partyjnego i bezpieki, wojskowych, inżynierów, lekarzy, uczonych oraz inne osoby, które przybywały do miasta razem z całymi rodzinami. Byli to osadnicy z Rosji, wschodniej i południowej Ukrainy, w mniejszym zakresie pochodzący z innych republik sowieckich (według narodowości byli to Rosjanie, Żydzi i Ukraińcy) ${ }^{1}$, którzy wraz z pozostałymi rdzennymi mieszkańcami miasta oraz nielicznymi jeszcze przybyszami z zachodnioukraińskich wsi², tworzyli nowe, powojenne społeczeństwo Lwowa. Nastanie tej rzeczywistości poprzedziły radykalne zmiany demograficzne w latach wojny: masowe aresztowania, zabójstwa i przymusowe wysiedlenia w czasie pierwszej okupacji sowieckiej (1939-1941) ${ }^{3}$, zagłada Żydów w czasie okupacji niemieckiej i deportacja Polaków w latach 1944-1946. Wydarzenia te przyczyniły się do zaniku dwóch najwięk-

${ }^{1}$ І. Терлюк, Росіяни західних областей України (1944-1996 рр.). (Етносоціальне дослідження), Львів 1997; А. В илєгала, Росіяни і російськомовне населення в сучасному Львові, [w:] Нове суспільство в давньому місті. Пам'ять та історична політика засобами oral history, вид. Л. Генке, Г. Россолінський, Ф. Тер, Вроцлав 2007, s. 237-256.

${ }^{2}$ Г. Бодн ар, Львів. Щоденне життя міста очима переселенців із сіл (50-80-ті роки XX cm.), Львів 2010.

3 Т. Вронська, Заручники тоталітарного режиму. Репресії проти родин „ворогів народу” в Україні (1917-1953 рр.), Київ 2009. 
szych przedwojennych wspólnot żyjących we Lwowie stanowiących aż 80\% populacji miasta $^{4}$. Do 1944 r. przeżyło mniej niż 1\% lwowskich Żydów, a w 1955 r. do polskości przyznawało się zaledwie 8,5 tys. lwowiaków $(2,3 \%)^{5}$. Większość rdzennych Ukraińców była represjonowana przez władze sowieckie w drugiej połowie lat 40. XX w. Tylko część z nich zdążyła wcześniej wyemigrować na Zachód. Tymczasem powojenni imigranci ze Wschodu swobodnie zasiedlali opuszczone mieszkania w centralnej części miasta, wcześniej należące do Żydów i Polaków. Jeśli głowa rodziny, która żyła w mieście w latach 1939-1941, przeżyła wojnę, to cała rodzina mogła wrócić i zamieszkać we Lwowie ${ }^{6}$. Tego prawa pozbawione były natomiast żony tych sowieckich wojskowych oraz partyjnych i państwowych urzędników, którzy nie przeżyli wojny, nie ustępowały jednak w staraniach, aby do Lwowa przyjechać.

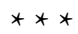

Spuścizna archiwalna z czasów sowieckich we Lwowie to nieprzebrane ilości dokumentów urzędowych: uchwał, rezolucji, protokołów, stenogramów, rozporządzeń, sprawozdań statystycznych, zaświadczeń itd. W zachowanej w lwowskich archiwach spuściźnie dotyczącej II wojny światowej przeważają akta dokumentujące liczby zmarłych i rozmiary poniesionych strat. Na tym tle szczególnie interesująco prezentują się materiały archiwalne lwowskiej Rady Miejskiej z lat 1944-1945. Wśród nich znajdują się bowiem podania do władz miasta o wyrażenie zgody na osiedlenie się we Lwowie ${ }^{7}$, w tym wspomnianych kobiet - żon sowieckich wojskowych. Mimo że historycy znają te materiały, wciąż nie zostały one należycie opracowane i wykorzystane, a ukazują mało znaną historię powojennego Lwowa. W listach tych odkrywamy bowiem historie życia, emocje i zmartwienia, strategie behawioralne wielu mieszkańców państwa totalitarnego, jakim był Związek Sowiecki. Inaczej mówiąc, listy te poprzez ukazanie indywidualnego doświadczenia wojny odzwierciedlają szersze zjawiska i procesy tytułową „wojnę w jednym losie”. Z powodu braku dokładnych danych statystycznych na temat powojennej migracji stosunkowo duża liczba wspomnianych listów pozwala

${ }^{4}$ Według spisu mieszkańców miasta sporządzonego w 1931 r. ponad połowa mieszkańców miasta (50,44\%) to rzymscy katolicy (Polacy), 31,9\% - Żydzi i 15,93\% - grekokatolicy (Ukraińcy). С. Макар чук, Евакуація поляків зі Львова у 1944-1946 pp., [w:] Lwów. Miasto, społeczeństwo, kultura. Studia $z$ dziejów miasta, t. 4, red. K. Karolczak, Kraków 2002, s. 401.

5 В. Сусак, Етнічні та соціальні зміни в населенні Львова в 1939-1999 роках. Магістерська робота. Львівський національний університет ім. І. Франка, Львів 2000, s. 80.

${ }^{6}$ Г. Бодн ар, Житло як тягар і привілей. До питання про способи радянізації Львова у другій половині 1940-х років, [w:] Lwów. Miasto, społeczeństwo, kultura. Studia z dziejów Lwowa, t. 9: Życie codzienne miasta, red. K. Karolczak, Ł. T. Sroka, Kraków 2014, s. 413-443.

7 Державний архів Львівської області, Львів (dalej: ДАЛО), ф. Р-6: Виконавчий комітет Львівської міської ради депутатів трудящих, оп. 2, спр. 10-19: Заяви і відношення громадян і установ на видачу дозволу на в'їзд в м. Львів, 10 томів, 12 IX - 30 XII 1944; спр. 22: Листи громадян, надіслані з інших міст з проханням вислати дозвіл на в’їзд в м. Львів, 26 XII 1944 - 20 VII 1945; спр. 43 : Заяви військовослужбовців про дозвіл на в'їзд в м. Львів, 26 X - 22 XII 1944; спр. 45: Документи перевірок скарг трудящих (постанови, акти, листування), 19 IX - 29 XII 1944; спр. 103-147: Заяви і відношення громадян і установ на видачу дозволу на в"їд в м. Львів, 45 томів, 1945; спр. 149: Листи громадян, надіслані з інших міст з проханням на в’їзд в м. Львів, 28 VI - 4 X 1945 та ін. 
spojrzeć „z bliska” na powojenne losy mieszkańców Lwowa oraz osób aspirujących do tego miana. Dokumenty te obrazują nie tylko historię życia tych ludzi, ale także strategie zachowań, posiadane możliwości czy ich brak, modele współpracy z władzą, motywacje i konkretne działania. Każdy z petentów zwracających się do Rady Miejskiej Lwowa o zgodę na przeprowadzkę do miasta kierował się innymi okolicznościami życiowymi. Część osób nie mogła się oprzeć pokusie, by wrócić do wymarzonego miasta po krótkotrwałym pobycie w nim w latach 1939-1941 podczas pierwszego okresu rządów sowieckich we Lwowie. Za jeszcze innymi podaniami kryły się zupełnie odmienne intencje

W niniejszym tekście będę odwoływać się do terminu zaproponowanego przez Kennetha Plummera: „dokumenty osobiste”. Przez pojęcie to autor rozumiał listy, dzienniki, notatniki, wspomnienia, zdjęcia, pamiętniki itd. napisane co prawda na własny użytek, ale przeznaczone też dla innych. Zawarte w dokumentach osobistych relacje bezpośrednich uczestników wydarzeń, opisywane rozterki i działania, pragnienia oraz marzenia, emocje, w końcu światopogląd twórców tego typu materiałów potrafią znacząco poszerzyć naszą wiedzę o przeszłości. Odczytywanie dokumentów osobistych to proces „odszyfrowywania i produkcji”, mówiąc inaczej - „znaczenia są wczytywane i wyczytywane”, dokumenty tego typu "potrafią zauroczyć swoją niezwykłością i szczerością niczym przez przypadek podsłuchana rozmowa"9 . Jak pisze rosyjska badaczka, Natalja Kozłowa:

Zachodzi coś podobnego do cudu powstawania metafory. Zestawianie całkowicie różnych przedmiotów i właściwości uwalnia to, co powszechne... Historia dokonana - to suchy liść, liść postrzępiony, cały w dziurkach. Jak się spojrzy na światło, to nie zobaczy się nic poza szkieletopodobną siatką. Potrzebny jest wysiłek, by przywrócić mu wygląd żywego liścia, żeby nadać wydarzeniom tę pełnię, którą czuł ten, kto je przeżywał. W każdym razie zaczynasz żywić sympatię do tego społeczeństwa, której nigdy wcześniej nie czułeś. Przeżywasz szok z powodu przeszłości, która przed chwilą jawiła się jak żywa... ${ }^{10}$

Do określania relacji społecznych znani socjolodzy Pierre Bourdieu, Norbert Elias i Ludwig Wittgenstein wykorzystują metaforę gry:

Dla wyników gry społecznej nie jest tak ważne, czy jej uczestnicy grają zapamiętale i chętnie, bez słowa, niechętnie czy też „niepoważnie”. Najważniejsze, że zgadzają się na grę, grają w nią. Póki zasady są respektowane, społeczeństwo żyje. Dopóki ludzie się bawili w zebrania partii i Komsomołu, dopóty istniało społeczeństwo sowieckie ${ }^{11}$.

Doświadczenie indywidualne ilustruje zachowanie konkretnego człowieka jako jednostki oraz jako członka grupy/społeczeństwa, pozwala na rekonstrukcję wizji

\footnotetext{
${ }^{8}$ Н. Козлова, Советские люди. Сцены из истории, Москва 2005, s. 19.

9 О. Коляструк, Документи особового походження як джерела з історії повсякденності, „Український історичний журнал” 2008, вип. 2, s. 145.

${ }^{10}$ Н. Козлов а, op. cit., s. 20. Ten i kolejne cytaty w tłum. aut. (przyp. red.).

${ }^{11}$ Ibidem, s. 63.
} 
świata tego, kto ją stworzył, a więc pozwala na mówienie o społeczeństwie w ogóle. Francuski filozof Jean-Paul Sartre pisał:

(...) człowiek nigdy nie jest wyłącznie jednostką; należy go raczej nazwać jednostką uniwersalną. Stotalitaryzowany oraz zuniwersalizowany przez swoją epokę człowiek na nowo ją totalizuje, odtwarzając siebie w niej jako jednostkę. Uniwersalny poprzez jednostkową uniwersalność historii poszczególnego człowieka, jednostkowy poprzez uniwersalizującą jednostkowość swoich projekcji, musi być rozpatrywany jednocześnie z obu perspektyw ${ }^{12}$.

Bez analizy „świata wyobrażeń” poszczególnych jednostek nie da się wyjaśnić, dlaczego różni ludzie w odmienny sposób reagują na „jeden i ten sam fenomen” (twierdzenie Williama Thomasa) ${ }^{13}$.

Praca $z$ dokumentami osobistymi zmusza badacza do znalezienia się na pograniczu rzeczywistości i faktografii oraz abstrakcji myślenia teoretycznego. $Z$ jednej strony jest to praca z ludźmi, żywymi świadkami przeszłości, którzy pozostają na zawsze $\mathrm{z}$ badaczem na zawsze, nawet gdy w przyszłości będzie on badał inne świadectwa, z drugiej zaś - z unikatowymi, samowystarczalnymi historiami życiowymi i wydarzeniami; poprzez wnikliwe odczytywanie egodokumentów wchodzi się w cudzy rytm życia, wyłapuje każdy szczegół. Patrząc z jeszcze innej perspektywy, jest to zejście do uogólnień oraz uświadomienia teoretycznego, innymi słowy, grounded theory (teoria ugruntowana). Zrozumienie znaczenia faktów i zjawisk następuje po „zanurzeniu się" badacza w badaną materię, a wnioski kształtują się na końcowym etapie analizy poprzez wyodrębnianie tematów bądź dokonanie uogólnionych sądów z tekstów/ zgromadzonych relacji (wypowiedzi, fragmentów dokumentów lub transkrypcji wywiadów) w celu otrzymania całościowej wizji ${ }^{14}$ : „Zdarza się, że poprzez przypadkowe frazy i wypowiedzi można wypracować najbardziej trafną ocenę badanego zjawiska, wtedy nieoczekiwana fiksacja przypadku odzwierciedla regularność, a akcentowana odrębność pokazuje typowość zjawiska"15.

Badając relacje - zarówno ustne, jak i pisemne - zawsze chce się wniknąć do prawdziwej rzeczywistości stojącej za tekstem. Tradycyjnie język jest traktowany jako pośrednik pomiędzy badaczem a rzeczywistością z przeszłości, który przekazuje niezmienne oraz jedyne znaczenia. Pierwszorzędne jest to, co jest opowiadane, a nie to, jak to jest lub nie jest robione. Potencjał rekonstrukcyjny źródła pozostaje ważny i wciąż jest wykorzystywany w pierwszej kolejności. Jednak wyraźnie subiektywna „literatura faktu” jest wdzięcznym polem do „analizy tekstowej”, czyli takiego badania tekstu (wątku, opowieści), któremu towarzyszy skupienie uwagi badacza na osobli-

12 Ж.-П. Сарт р, Идиот в семье. Гюстав Флобер от 1821 до 1857, Санкт-Петербург 1998, s. 7.

${ }_{13}$ В. Фукс-Хайн ритц, Биографический метод, [w:] Биографический метод. История, методология, практика, ред. кол. Е. Мещеркин а, В. Семенов а, Москва 1994, s. 14.

14 В. Семенова, Качественные методы. Введение в гуманистическую соціологію, Москва 1998, s. 127.

${ }^{15}$ О. Коляструк, op. cit., s. 146. 
wościach tekstowych: osobliwościach wątku i charakterystyk tematowych, kolejności przedstawiania informacji, skojarzeniach, epizodach, dygresjach i wyjaśnieniach itd.

Opowieść przede wszystkim musi być rozpatrywana jako subiektywna rzeczywistość, jako świadectwo o własnej wewnętrznej strukturze (topowe tematy, pewne tabu, wykorzystywane tropy itp.), która odzwierciedla rzeczywistość w różnym stopniu i na różne sposoby. Poprzez zestawienie wątku wydarzeń opowieści oraz wypowiedzianych ocen analizie poddawane są struktury znaczeniowe opowieści, czyli to, w jaki sposób jest ona budowana, jak w niej jest lub nie jest brane pod uwagę doświadczenie życiowe, jakie są skala i wariacja struktur znaczeniowych („repertuar możliwości”) w tekście ${ }^{16}$. Brytyjski historyk i eseista, badacz tzw. „historii od dołu” Richard Cobb podkreślał: „Najbardziej utalentowani badacze wykazują gotowość, żeby się dosłuchać słów dokumentu, iść w ślady każdej jego frazy, nawet tej nieczytelnej (...) po to, by poczuć, co tak naprawdę zostało powiedziane, $\mathrm{z}$ jakim akcentem i jakim tonem" ${ }^{17}$. To, co wypowiedziane, jest przesiąknięte tym, co miano na myśli, ale i tym, co pozostało niedopowiedziane. Praca $\mathrm{z}$ opowieściami polega przede wszystkim na tym, by się w nie wczytać, „ «wgłębić się» w ich treść i na tej podstawie wyodrębnić «kognitywne figury», które z kolei są poddawane wielokrotnej analizie pod postacią "koła hermeneutycznego»"18. Natalja Kozłowa pisze, że „obecnie socjolog, historyk, antropolog nie może nie brać pod uwagę tego, że ma do czynienia ze światem, który już był przedyskutowany i został zrozumiany, określony i sklasyfikowany za pośrednictwem języka"19.

Język jest bezpośrednio związany z działalnością podmiotu, odzwierciedla jego doświadczenia, to, co robił, robi i planuje zrobić. Jednak język też podporządkowuje indywiduum swoim strukturom. Przecież jednostka korzysta z gotowych zasad ukształtowanych przez język, przede wszystkim odpowiednio do epoki i panującej retoryki („klisze, metafory, jednostki dyskursu”) ${ }^{20}$. W jednym z artykułów Ołeny Stiażkiny czytamy: „Jak udowodnił Michel Foucault, każdy język jest skolonizowany poprzez własne znaczenia, a zdaniem Jacques’a Derridy każde pismo organizuje siebie niezależnie od swojego autora poprzez środki zrytualizowane i niekrytycznie odtwarzane praktyki"21.

Powojenne listy pozwalają odkryć, w jakiej mierze to, co „sowieckie” („standardowe formuły ideologii epoki sowieckiej”, „figury mowy ideologii tej epoki”), jest obecne/zakorzenione w przedstawianiu/pojmowaniu przez autorów własnej historii. Olha Koliastruk pisze: „Niektóre frazy mogą się wydawać głośne i puste, kiedy są czy-

${ }^{16}$ Н. Цветаева, Советский биографический дискурс, „Социологический журнал” 1999, № $1 / 2$, s. 111.

${ }_{17}$ Суt. za: Д. Тош, Стремление к истине. Как овладеть мастерством историка, Москва 2000, s. 101.

${ }^{18}$ Н. Цв ет аев а, Советский биографический дискурс.., s. 111.

19 Н. Козлов а, op. cit., s. 46.

20 Ibidem.

${ }_{21}$ Cуt. za: О. Стя жкін а, Володарі часу. Чому радянське (не)завериується, [w:] Радянськість. Спроба діагностики крізь призму повсякденності. 36. матеріалів II Всеукр. наук-теорет. семінаpy, 7-8 квітня м. Вінниия, відп. ред. О. Коляст трук, Вінниця 2017, s. 74-75. 
tane z historycznie bezpiecznej odległości, chociaż niegdyś zawierały wyraźną treść. Takie figury kultury języka są dla nas pozostałościami dawnych dziejów, ale wówczas to one kształtowały życie"22.

Poza tym należy uwzględnić, że każdy list ma dwóch autorów: tego, kto go napisał, oraz tego, do kogo był on pisany, przecież pisząc tekst, jego autor od razu orientuje się na tego, kto będzie go czytał; co najmniej w połowie to odbiorca określa styl i ukierunkowanie listu ${ }^{23}$. Potencjalny odbiorca jest ciągle obecny w procesie wewnętrznego kształtowania i wyrażania myśli przez autora. Poza tym analizie poddawane są listy do władz - nie są to więc zwyczajne listy, tylko życiorysy, wnioski i prośby zarazem.

\section{Baza źródłowa}

Podstawą źródłową niniejszego tekstu są materiały Komisji ds. Udzielania Zezwoleń na Przyjazd do Lwowa w okresie od września 1944 r. do grudnia 1945 r. Są one przechowywane w zespole Lwowskiej Rady Miejskiej (P-6: Komitet Wykonawczy Lwowskiej Rady Miejskiej Deputowanych Pracujących). Spuścizna ta zawiera podania, listy, apele, raporty, które ze względu na treść wniosku oraz uzyskaną pozytywną bądź negatywną odpowiedź można podzielić na dwie grupy.

Do pierwszej należą listy-wnioski migrantów ze wschodnich regionów Ukrainy oraz innych republik ZSRS, przeważnie z Rosji, którzy w drugiej połowie $1944 \mathrm{r}$. i w 1945 r. mieszkali i pracowali we Lwowie (przybyli do Lwowa wraz z Armią Czerwoną bądź zostali skierowani do pracy, począwszy od sierpnia 1944 r.) oraz chcieli przenieść do Lwowa swoją rodzinę i udało im się to dzięki otrzymaniu pozytywnej decyzji. Biorąc pod uwagę brak dokładnych danych statystycznych na temat powojennej migracji oraz to, że nie istniała możliwość swobodnego wjazdu do miasta, analiza treści ponad dwustu wniosków pozwala na lepsze zrozumienie problemu zasiedlania Lwowa w latach 1944-1945 przez osoby pochodzące z Rosji i południowo-wschodniej Ukrainy. Analiza podań pozwala także ustalić, skąd osoby te przywiozły swoje rodziny, gdzie we Lwowie zamieszkały oraz czym się wyróżniały na tle społeczności miasta. Podania te zawierają jednak mało dygresji biograficznych, pozbawione są też emocjonalności. Materiałom tym poświęciłam już uwagę w innym miejscu ${ }^{24}$.

W centrum niniejszego badania znalazła się natomiast druga kategoria listów. Są to listy „obywateli, wysłane $\mathrm{z}$ innych miast z prośbą o udzielenie zezwolenia na przyjazd do miasta Lwowa”, na które władze udzielały odpowiedzi negatywnych ${ }^{25}$. Listy te były pisane przez osoby z różnych zakątków Rosji i Ukrainy, ale także z innych republik ZSRS. Ich autorami byli lwowianie oraz mieszkańcy Ukrainy Zachodniej ewakuowani w latach 1939-1941 oraz częściowo deportowani w latach 1940-1941.

22 О. Коляструк, op. cit., s. 147.

23 В. Семенова, op. cit., s. 112.

24 Г. Боднар, Житло як тягар і привілей..., s. 413-443; е a de m, Жити в омріяному місті. Заяви-прохання повоєнних мешканців Львова про дозвіл на переїзд родини (1944-1945 роки), „Вісник Львівського університету. Серія історична" [w druku].

25 ДАЛО, ф. Р-6, оп. 2, спр. 22. 
Zabierając się do pisania listów, ich autorzy uświadamiali sobie możliwość uzyskania decyzji odmownej, ale mimo to starali się napisać podanie tak, by ich prośba została rozpatrzona pozytywnie. $\mathrm{W}$ tym celu w liście podawano życiorys, podkreślając zwłaszcza te momenty, które mogłyby dopomóc w uzyskaniu zezwolenia na powrót do Lwowa. Pomijano w nich natomiast wszystko to, co mogło stanowić przeszkodę w pozytywnym rozpatrzeniu sprawy. Ci, którzy nie potrafili się dostosować do sowieckich norm, byli negatywnie odbierani przez władze, zajmowali niższe stanowiska w społeczeństwie, czyli mówiąc kolokwialnie, „przegrywali”, w tekstach listów starali się zaprezentować jak najlepiej, odgrywali określoną rolę niczym aktorzy ${ }^{26}$. Przed czytelnikiem jawi się cały kalejdoskop życiowych historii, nie jest też prawdą, że w społeczeństwie sowieckim nie można było dokonywać żadnego wyboru.

Listy były wysyłane pod adresem Komisji bezpośrednio do Lwowskiej Rady Miejskiej albo były przekierowywane z Lwowskiej Rady Obwodowej, kijowskich bądź ogólnozwiązkowych resortów. Pisma adresowano także do Nikity Chruszczowa oraz wyższych funkcjonariuszy sowieckich. Zasadniczo listy z podaniami o zgodę na osiedlenie się we Lwowie zaczęto pisać w grudniu 1944 r., ale znane są też przypadki wcześniejsze - z sierpnia 1944 r. (urodzony we Lwowie Żyd chciał wrócić do rodzimego miasta, ponieważ poszukiwał rodziny, która w czasie wojny pozostała we Lwowie ${ }^{27}$ ).

Listy pisane do władz Lwowa mają charakter zarówno informacyjny, jak i niekiedy emocjonalny, część z nich jest pisana językiem urzędowym, inne posiadają walory literackie (według klasyfikacji Williama Thomasa oraz Floriana Znanieckiego) ${ }^{28}$. Teksty te zawierały szczegółowy opis życia nadawców, były pisane w taki sposób, by wywołać współczucie decydentów. Swoje losy nadawcy listów ukazywali jako unikatowe - w ten sposób chciano uzyskać pomoc.

Wbrew opiniom niektórych badaczy, że nie wszystko w prywatnej korespondencji, niekiedy przydługawej, jest warte badania (Gordon Allport, amerykański psycholog, założyciel psychologii osobowości, autor znanej pracy Letters from Jenny) ${ }^{29}$, listy do władz powojennego Lwowa wydają się krótkie i konkretne. Nadawca każdego listu podkreślał swoją własną wyjątkowość, a rozwój wątków miał jedynie pogłębić tę unikatowość. Dlatego starałam się poddać analizie cały badany materiał.

\section{Listy wdów do władz miasta Lwowa}

Listy osób, którym nie udało się uzyskać pozytywnej decyzji, można podzielić na jeszcze kilka pomniejszych grup według tego, kim byli ich nadawcy:

- kobiety zamieszkałe we Lwowie między wrześniem 1939 a czerwcem 1941 r., których mężowie polegli na froncie;

26 Н. Козлова, op. cit., s. 61.

27 ДАЛО, ф. Р-6, оп. 2, спр. 22, k. 8: Лист Гана Мойсея Йосиповича голові Раднаркому УРСР

Н. С. Хрущову, м. Ленінобад Таджицької РСР, VIII 1944.

28 B. Семенова, op. cit., s. 111.

${ }^{29}$ G. Allp ort, Letters from Jenny, New York 1965; В. Семен ов а, op. cit., s. 112. 
- Żydzi pragnący powrócić do rodzimego miasta oraz poszukujący swoich rodzin pozostałych we Lwowie w trakcie niemieckiej okupacji;

- jeszcze niezdemobilizowani mężczyźni, którzy planowali swoją przyszłość po zakończeniu wojny; wnioskowali oni o przeprowadzkę do Lwowa ich ewakuowanych na Wschód rodzin;

- „ewakuowani”, jak sami siebie określali wnioskujący, czyli tak naprawdę deportowani w 1940 r. (rzadziej w 1941 r.) mieszkańcy Lwowa oraz innych miejscowości z obszaru Ukrainy Zachodniej;

- młodzi ludzie, którzy jeszcze nie założyli rodzin, a którzy chcieli przenieść się do Lwowa, by tu pracować („odbudowywać miasto”); prosili o przydzielenie im niewielkich powierzchni mieszkaniowych.

Spośród wymienionych powyżej grup najwięcej odmów na zapytanie o możliwość sprowadzenia się do Lwowa udzielono wdowom po poległych sowieckich wojskowych albo żonom żołnierzy, którzy w trakcie wojny przepadli bez wieści. Udzielano im standardowej odpowiedzi w języku rosyjskim: „Komitet wykonawczy Lwowskiej Rady Miejskiej zawiadamia, że Komisja Urzędowa nie może udzielić czasowego zaproszenia".

Wnioskodawczynie powoływały się na uchwałę Rady Komisarzy Ludowych ZSRS z 5 sierpnia 1941 r. nr 1931 O zachowaniu powierzchni mieszkalnej na korzyść wojskowych oraz o trybie wnoszenia opłaty za powierzchnie mieszkalne przez rodziny wojskowych w czasach wojennych. Dokument ten przewidywał, że w okresie wojny wszyscy, którzy walczyli w szeregach armii sowieckiej, w marynarce czy NKWD mieli prawo do zachowania swoich mieszkań. Dlatego po wojnie mieszkania zasiedlone przez wojskowych w latach 1939-1941 były przywracane im na własność. Tymczasowi mieszkańcy takich lokali, którzy zajęli je po 1941 r., musieli je opuścić po powrocie wojskowego, $\mathrm{w}$ przeciwnym razie byli wysiedlani w trybie administracyjnym bez udzielenia im zastępczej powierzchni mieszkalnej. Mieszkania nie były jednak przywracane wdowom wojskowych, jedynie tym kobietom, których mężowie wracali $\mathrm{z}$ frontu i byli kierowani do pracy do Lwowa.

Wdowy powoływały się też w swoich podaniach na Rozporządzenie Rady Komisarzy Ludowych ZSRS z 28 kwietnia 1943 r. nr 462 O zapewnieniu warunków do życia dla rodzin generałów i osób z dowództwa Armii Czerwonej zmarłych, poległych na polu walki oraz przepadłych bez wieści na froncie, zgodnie z którym, ich zdaniem, rodzinom starszego dowództwa oraz poległych na froncie należało się prawo do przeprowadzki do każdego miasta w Związku Sowieckim z prawem do otrzymania mieszkania i miejsca pracy ${ }^{30}$. Tak naprawdę w rozporządzeniu chodziło o dowolny wybór miejsca zamieszkania pod warunkiem posiadania mieszkania na terenach okupowanych. W 1945 r. zezwolenie na przyjazd do Lwowa udzielano jedynie pod warunkiem potwierdzenia posiadania mieszkania w mieście ze względu na brak wolnych powierzchni mieszkaniowych. Na przykład żona majora NKWD, której

30 ДАЛО, ф. Р-6, оп. 2, спр. 22, k. 45-45v: Лист Короткевич Єви Олексіївни голові Ради народних комісарів УРСР, м. Коканд Ферганської обл. Узбекистану, 22 V 1945. 
w okresie okupacji niemieckiej udało się ukryć w regionie sumskim, w 1944 r. zrezygnowała ze skierowania do Lwowa na korzyść Izmaiła (miasta w obwodzie odeskim), a gdy w sierpniu 1945 r. starała się jednak o Lwów, to już nie mogła się przeprowadzić ze względu na brak mieszkania ${ }^{31}$.

Kobietom odmawiano niezależnie od statusu i miejsca pracy. Na przykład odrzucono wniosek wdowy kierownika oddziału kontrwywiadu „Smersz” (poległ w październiku 1944 r.), która mieszkała we Lwowie od listopada 1939 do czerwca 1941 r., zajmowała odpowiedzialne stanowiska - inspektora obwodowego oddziału ds. zaopatrzenia przez państwo rodzin wojskowych w mieście Czkałow (obecnie Orenburg, Rosja), a w momencie składania wniosku - NKWD miasta Dzierżyńsk (obecnie Toreck w obwodzie donieckim).

Wdowy wnosiły o powrót do Lwowa również ze względu na to, że podczas ewakuacji w czerwcu 1941 r. pozostawiły tam swoje rzeczy, podkreślały, jak ciężkie jest życie bez własnego mieszkania na ewakuacji, oraz potwierdzały posiadanie „własnego" mieszkania w mieście ${ }^{32}$. Autorki listów podkreślały, że ich mężowie albo polegli, albo walczą dla dobra kraju. Barwne, szczegółowe oraz bardzo szczere są listy kobiet, które czuły się porzucone i bezradne. Żona starszego oficera, ewakuowana ze Lwowa 23 czerwca, posiadająca „lwowski paszport” wnosiła o zezwolenie na przyjazd do Lwowa w celu odzyskania ukrytych (zakopanych) rzeczy, których miało jej jakoby starczyć do końca życia; powierzchnia mieszkania interesowała ją dopiero na drugim planie. Nie patrząc na trudną sytuację finansową, kobieta nadała swoją prośbę listem poleconym, co zdarzało się w owych czasach rzadko:

(...) rzeczy są zakopane tam, gdzie mieszkałam, myślę, że są całe, ponieważ są zakopane [słowo zostało podkreślone atramentem innego koloru, prawdopodobnie przez osobę, która czytała list - H.B.] i komukolwiek będzie ciężko je znaleźć, obecnie jestem w bardzo trudnej sytuacji... i mam nadzieję, że rzeczy, które są tam zakopane, starczą mi na całe moje życie... [podkreślono innym kolorem - H.B.], dlatego usilnie proszę, by towarzysz przewodniczący wysłał mi zezwolenie na wjazd do miasta Lwowa chociaż tymczasowo, żeby zabrać rzeczy, które tam pozostały. Moje mieszkanie pozostało, rozmiar mieszkania 74 metry kwadratowe, a ja potrzebuję jedynie $15 \mathrm{~m} \mathrm{kw}^{33}$

Przed śmiercią swoich mężów wojskowych, zajmujących wysokie stanowiska w dowództwie armii, kobiety mało dbały o zaspokojenie codziennych potrzeb rodziny, były przywykłe do życia na garnuszku państwa i różnych ulg. Warwara Kowalowa, wdowa po komisarzu brygadowym, poległym w 1941 r., ewakuowana do Czernihowa, powoływała się na swoje prawo do powrotu do Lwowa, a na dodatek wystarała się o potwierdzenie przez lwowską prokuraturę, że po jej przyjeździe mieszkanie przy ul. Kochanowskiego 91 (obecnie ul. K. Lewickiego), które uprzednio zajmowała, zo-

31 Ibidem, k. 99-99v: Автобіографія Худзінської Олександри Янівни, 20 IV 1945.

32 Ibidem, k. 60: Лист Пєтухової Анни Семенівни, м. Іваново Росії, VIII 1945.

33 Ibidem, k. 55: Лист Калініної Н. М. до голови виконкому Львівської обласної ради, м. Стариця тепер Тверської обл. Росії. 
stanie dla niej zwolnione ${ }^{34}$. Kobieta starała się nie tylko o umożliwienie przyjazdu do Lwowa dla swojej najbliższej rodziny, ale także dla innej krewnej (też wdowy) z synem, ponieważ ta jej pomagała i bez niej czuła się całkowicie bezradna. Akcentując wysokie stanowisko poległego męża, Kowalowa prosiła o przydzielenie jej całego wagonu w pociągu towarowym celem przewiezienia do Lwowa majątku i zapasów żywnościowych - powoływała się przy tym na przykład żony pewnego partyzanta, której zapewniono takie udogodnienia:

Jestem całkowicie chora i bez niej [wspominanej w liście krewnej - H.B.] absolutnie nie daję rady. Fizycznie nie jestem w stanie nic robić, ona w gruncie rzeczy wychowuje moje dzieci. Mój mąż służył w wojsku przez 23 lata. Był wyższym kierownikiem magazynu, obecnie byłby już generałem i możliwość przeprowadzki nie stanowiłaby żadnego problemu, dlatego proszę przydzielić mojej rodzinie wagon celem przeprowadzki do miasta Lwowa. Jechała stąd żona partyzanta i jej wagon przydzielono. Do wagonu zabrałabym ziemniaki z pola, dzięki czemu mogłabym przeżyć zimę we Lwowie. Mam nadzieję, że Państwo wezmą pod uwagę to, ile ja przeszłam, straciłam prawie wszystko: męża, cały majątek. Pozostały mi tylko głowa i dwójka dzieci... ${ }^{35}$

Wojna zmuszała kobiety do brania na siebie dotychczasowych obowiązków męża. „Po tragicznej śmierci męża zajęłam jego miejsce i wciąż należę do szeregów Armii Czerwonej. Niedługo zostanę zdemobilizowana” - pisała w liście do przewodniczącego Lwowskiej Rady Miejskiej Jewdokija Pikułenko, młodszy porucznik, członkini Ogólnozwiązkowej Komunistycznej Partii Bolszewików, z wykształcenia nauczycielka historii ${ }^{36}$.

Zdarzały się też wnioski pisane przez samodzielne kobiety, zajmujące stanowiska kierownicze. Takie listy ukazują nie zdaną wyłącznie na pomoc z zewnątrz wdowę, ale przede wszystkim matkę, głowę rodziny. Dobrym przykładem takiej postawy może być deputowana Obwodowej i Miejskiej Rady Lwowa, która chciała pracować (w latach 1939-1941 zajmowała stanowisko kierownika hali we lwowskich zakładach wojskowych) i nadal pomagać „swoim wyborcom” ${ }^{37}$. Okupację niemiecką, która zmusiła ją do „ewakuacji”, traktowała jedynie jako tymczasową niedogodność, która zmusiła ją do przerwania na chwilę jej życie we Lwowie. Jej zdaniem jeszcze w okresie trwania wojny (zimą-wiosną 1945 r.) nabyła ona prawo do powrotu i kontynuowania swojego „przedwojennego” lwowskiego życia.

Listy wnioskujących o możliwość zamieszkania we Lwowie to przykłady dyskursu matki-opiekunki dzieci, rzadziej w listach tych podejmowane są kwestie zdolności

${ }_{34}$ Ibidem, k. 79: Відповідь виконкому Львівської міської ради з відмовою у видачі виклику Ковальовій В. Ф., VIII 1945 р.; k. 84: Відповідь на лист гр. Ковальової прокурора Сталінського р-ну м. Львова.

${ }_{35}$ Ibidem, k. 81-81v: Заява Ковальової Варвари Федосіївни голові РНК УРСР, м. Сичовка Смоленської обл. Росії, 10 VIII 1945.

${ }^{36}$ Ibidem, k. 107-107v: Лист Пікуленко Євдокії Семенівни до голови Львівської міської ради, м. Запоріжжя, 1945.

37 Ibidem, k. 127-127v: Заява Реутової Наталії Миколаївни до голови Львівської обласної ради, м. Магнітогорськ Росії, 5 III 1945. 
zawodowych i kwalifikacji kobiet. Dzieci po utracie żywiciela rodziny żyły w nędzy oraz w trudnych warunkach klimatycznych. To one były jednym $\mathrm{z}$ najważniejszych argumentów przy kierowaniu próśb o przeprowadzkę i to one były główną podstawą żywienia nadziei, że prośby te spotkają się ze zrozumieniem władz Lwowa. „Moje dzieci straciły ojca, straciły też wszystko inne” - tłumaczyła wdowa ewakuowana wraz z jedną córką w mieście Baku w Azerbajdżanie (drugą córkę zostawiła u rodziny męża w obwodzie donieckim). Pisała: „Proszę wziąć pod uwagę wszystko wyżej powiedziane oraz pomóc mi, żebym mogła je wyhodować [!] i wychować na godnych obywateli Związku Sowieckiego"38. Ciągłe przeprowadzki wraz z dziećmi, brak stałego miejsca zamieszkania, doskwierająca nędza - wszystko to przypominało nadawczyniom listów życie Cyganów ${ }^{39}$.

Pośród przebadanej dokumentacji rzuca się w oczy jedna pozytywnie rozpatrzona prośba wdowy po kierowniku oddziału agitacji i propagandy Lwowskiej Rady Miejskiej, majorze lotnictwa. Otrzymała ona dwie odmowy na prośby o umożliwienie zamieszkania we Lwowie, ale to jej nie zniechęciło. W listach apelowała do wszystkich, do kogo się dało - od kierownika Oddziału Skarg Komitetu Wykonawczego Lwowskiej Rady Miejskiej po przewodniczącego Rady Komisarzy Ludowych USRS Nikity Chruszczowa. W ten sposób udało się jej osiągnąć swój cel. Jej listy to wyraz determinacji załamanej kobiety, która zrozumiała, że we Lwowie czeka na nią wszystko, a w miejscu, gdzie ją ewakuowano (nawet nie podawała adresu) - życie w mieszkaniu z „czterema obcymi ludźmi” i ciągłym oczekiwaniu na przeprowadzkę, co uniemożliwiało jej podjęcie pracy. Pisała listy zarówno do drobnych lwowskich urzędników, do których zwracała się „jako bliskich i zaufanych ludzi”, powoływała się w nich na konkretnych sowieckich włodarzy Lwowa z lat 1939-1941, w końcu formułowała też i ostrzejsze żądania. Spotkały się one z pozytywnym rozpatrzeniem:

Z listu tow. Tomenki dowiedziałam się, że przekazano Panu mój list adresowany do tow. Chruszczowa z prośbą o udzielenie mi zezwolenia na wjazd do Lwowa. Minęło już sporo czasu, a ja niczego od Pana nie dostałam! Niedawno wysłałam list do przewodniczącego Rady Miasta tow. Kowanewa (przez przypadek poznałam nazwisko za pośrednictwem milicji obwodowej). Nie uspokoję się, póki nie dostanę zaproszenia. Jestem w sytuacji bez wyjścia. Nie idę tu do pracy, ponieważ czekam na zaproszenie. Jestem w nieokreślonym miejscu i stanowisku, w stanie wyczekiwania już od 4 lat. Mam wiele powodów, by móc wiedzieć. Proszę Pana jako towarzysza i człowieka sowieckiego o natychmiastowe udzielenie mi odpowiedzi. Sądzę, że Pan uświadamia sobie swój obowiązek jako rady miejskiej deputowanych pracujących ${ }^{40}$.

${ }^{38}$ Ibidem, k. 92-92v: Заява Лойченко-Гриневич О. А. до голови виконкому Львівської обласної ради, м. Баку, Азейбаджан, 10 VIII 1945.

${ }^{39}$ Ibidem, k. 104-104v: Лист Петровської Л. Н. до голови Ради Народних Комісарів СРСР В. Молотова, 1945.

40 Ibidem, k. 121: Заява Квактун Євгенії Аронівни до «відділу видачі пропусків, тов. Морозу» Львівської міської ради, Головпоштамт (до вимоги), VIII 1945. 
Przeprowadzić się na stałe do Lwowa chcieli ludzie w różnym wieku i o różnym statusie, często były to osoby pochodzące z Rosji (obwód moskiewski, stalingradzki). Osoby te przeważnie nie umiały przedstawić precyzyjnych argumentów uzasadniających potrzebę przeprowadzki. Argumenty najczęściej spotykane w takich listach to: "chęć przeprowadzki do Lwowa na stały pobyt” czy „ogromna chęć pracowania we Lwowie”. Wśród takich wnioskodawców najwięcej było młodych, jeszcze niezamężnych bądź samotnych kobiet. Na przykład pani Cwietkowa (list podpisany tylko nazwiskiem) w swoim liście podawała jedynie, że jest młoda (ur. w 1924 r.) i ma średnie wykształcenie. Aż trzykrotnie w tym podaniu pytała, jak można dostać zezwolenie na pobyt we Lwowie i jakie dokumenty są do tego potrzebne ${ }^{41}$. Absolwentka Instytutu Pedagogicznego w Tomsku, pracująca jako nauczycielka, urodzona w 1921 r., prosiła o możliwość zamieszkania we Lwowie i nauczania tu języka rosyjskiego i literatury ${ }^{42}$, a jej rówieśniczka, która uczęszczała dwa lata do Instytutu Pedagogicznego i miała doświadczenie w pracy jako nauczycielka i kasjerka, pytała: „Jeżeli mogą Państwo wykorzystać mnie do jakiejkolwiek pracy, to usilnie proszę o wystawienie mi zaproszenia" $^{33}$. O zaproszenie do pracy i wstępne zapoznanie się z przyszłymi warunkami pracy prosiła także kobieta urodzona w 1910 r. w obwodzie stalingradzkim (obecnie wołgogradzkim), z której długiego życiorysu dowiadujemy się, że była wychowanką domu dziecka, a aktualnie jest wdową. W momencie pisania listu wróciła z ewakuacji do Stalingradu (obecnie Wołgogradu) i pracowała jako księgowa ${ }^{44}$.

\section{Język listów}

Listy osób starających się o zgodę na przeprowadzkę do Lwowa to teksty zawierające krótkie, uargumentowane i konsekwentne przedstawienie sytuacji życiowej, zawierające ponadto szereg faktów z życiorysu, podawanych w celu potwierdzenia prawdziwości swojego położenia. Często podkreślano decyzja znaczenie decyzji urzędnika będącego adresatem listu. Na jednej, dwóch stronach tekstu proszący o zgodę na przyjazd do Lwowa usiłowali maksymalnie zwrócić na siebie uwagę sowieckiego urzędnika i zainteresować go swoim problemem, żeby od razu po przeczytaniu listu był on skłonny do podjęcia pozytywnej decyzji. Na końcu listu z reguły jeszcze raz podkreślano, że przedstawiona w liście prośba ma arcyważne znaczenie i wymaga jak najszybszej decyzji. Za pomocą listu usiłowano przyciągnąć uwagę właśnie do swojej sytuacji życiowej, by wyróżnić się na tle innych analogicznych próśb i otrzymać oczekiwaną pomoc. W niejednym liście pisano: „Moja prośba jest taka mała, ale dla mnie jest to kwestia życia”.

41 Ibidem, k. 34: Лист Цвєткової, м. Красногорськ Московської обл., Росія, 11 VII 1945.

42 Ibidem, k. 62: Заява Горлової Ірини до міськвиконкому м. Львова, Алтайський край Росії, VIII 1945.

43 Ibidem, k. 138: Лист Громенко Ніни Андріївни до голови виконкому Львівської міської ради, м. Грозний Росії, 1 VII 1945.

44 Ibidem, k. 36, 37-37v: Лист Кондратьєвої Діни Андріївни до голови облвиконкому м. Львова Західної Білорусі, м. Сталінград Росії, 4 VIII 1945. 
Wszystkie odrzucone prośby do powojennych władz we Lwowie były napisane w języku rosyjskim, nawet te napisane przez deportowane i ewakuowane osoby autentycznie wywodzące się ze Lwowa i obszaru Ukrainy Zachodniej (w tekstach ich autorstwa napotykamy jednak wyrazy w języku ukraińskim i polskim). Z kolei standardowe formularze oraz teksty decyzji władz Lwowa były podawane w języku ukraińskim. Od września do grudnia 1944 r. kancelaria Lwowskiej Rady Miejskiej korzystała z formularzy sporządzonych wyłącznie w języku ukraińskim, w języku ukraińskim udzielano też odpowiedzi na listy napisane po rosyjsku. Jednak od roku 1945 odmowy udzielenia zezwolenia na przeprowadzkę do Lwowa były pisane już w języku rosyjskim. Decyzje te były wpisywane do standardowych formularzy sporządzonych również w języku rosyjskim. Aczkolwiek w sierpniu i wrześniu 1945 r. zdarzało się jeszcze procedowanie $\mathrm{w}$ języku ukraińskim. I tak sekretarz komitetu wykonawczego Lwowskiej Rady Obwodowej wydał rozporządzenie, aby rozpatrzyć wniosek w języku ukraińskim na formularzu sporządzonym po ukraińsku, a instruktor komitetu wykonawczego jednej z rad rejonowych miasta po ukraińsku sporządził zaświadczenie o stanie mieszkania jednego z wnioskodawców.

Podczas lektury listów przede wszystkim rzucają się w oczy sytuacje skrajne. Są to zarówno teksty poprawne językowo, napisane językiem literackim, jak i całkowicie niepoprawne, będące zgromadzeniem słów bez jakichkolwiek znaków interpunkcyjnych, o niekonsekwentnym wywodzie (gubiony wątek, powtórzenia). Różny był też wygląd zewnętrzny listów - od napisanych na niedużych skrawkach papieru zwykłym ołówkiem bez znaków interpunkcyjnych aż do rozbudowanych i treściwych, napisanych starannym, kaligraficznym pismem $\mathrm{z}$ dołączonym poprawnie sporządzonym życiorysem.

Różne systemy wyobrażeń funkcjonujące w jednym społeczeństwie to efekt braku lub posiadania (ważne jakiego) wykształcenia ${ }^{45}$. W późnosowieckim okresie w tekstach autorstwa „wiejskiej” generacji (osoby pochodzące ze wsi, które przyłączały się do budowy sowieckiego systemu) zauważalna jest tendencja: im więcej szkół skończył autor tekstu (szkoła zawodowa, kursy specjalistyczne, technikum, instytut i in.), tym „gorliwiej był on skłonny bronić swojego pozytywnego stosunku do ideałów okresu sowieckiego mimo braku logiki w przedstawianej przez niego historii i wyznawanych ideałów" ${ }^{46}$. W okresie powojennym pozycja społeczna autorów listów nie pokrywała się z poziomem umiejętności posługiwania się językiem. Język tekstów wskazuje na pozycję społeczną, ale jednak tę z przeszłości, a nie zdobytą w warunkach sowieckiej rzeczywistości. Ci, którzy w powojennym społeczeństwie sowieckim zajmowali podporządkowane stanowiska, często pisali dużo lepiej niż nowo powstała elita społeczna, ponieważ przed wojną to właśnie oni należeli do średnich i wyższych warstw społecznych. W takich wypadkach można mówić o wypracowanym stylu indywidualnym,

${ }^{45}$ Н. Козлова, op. cit., s. 48.

${ }^{46}$ Н. Цв е таева, Биографические нарративы советской епохи, „Социологический журнал” 2000, № 1/2, s. 169-170. 
kiedy „im szersza staje się przestrzeń odmienności życiowych doświadczeń wyrytych w pamięci poszczególnej osoby, tym większe są szansy na indywidualizację" ${ }^{37}$.

Jeśli autor listu chciał dopasować się do ówczesnego dyskursu, musiał nauczyć się języka władzy: „Język sowiecki, sowiecki tryb myślenia i poglądów na świat oraz na siebie stopniowo stawał się wiodący, powszechny oraz taki, którego nie szło nie zauważyć bądź się go "nie nauczyć»" ${ }^{48}$. Kobiece teksty zawierają klisze językowe oraz cechuje je wpisywanie się w dyskurs propagandowy charakterystyczny dla ówczesnej przestrzeni informacyjnej. Znamienny jest list żony mechanika samochodowego, który pracował w strukturach NKWD: „Zwracam się z usilną prośbą, dla uczczenia wielkiego sowieckiego zwycięstwa nad faszystowskimi najeźdźcami, dać nam możliwość powrotu do naszego mieszkania"49.

W listach zarówno mężczyzn, jak i kobiet podkreślano swój lub męża udział w wojnie: „dwóch w naszej rodzinie to obrońcy Ojczyzny”, „inwalida wojenny”, „oficer armii”, „,inwalida wojenny, obrońca”, „żona poległego na froncie”, „matka poległego oficera" itd. W listach podkreślano to, co pasowało do obowiązującego dyskursu - „siostra Komsomolca..., rozstrzelanego w Polsce w 1925 r., oraz akceptowalne identyfikatory: „komsomołka”, „narodowości rosyjskiej”, „na terenach okupowanych nie znajdowała się”, „starzy członkowie partii”, ,żona komisarza brygadowego” i in. Od takich słów zaczynano listy oraz nimi je kończono.

Zwracają także uwagę genderowe osobliwości kobiecych tekstów. W odróżnieniu od tekstów autorstwa mężczyzn kobiece teksty, szczególnie pisane przez wdowy, są emocjonalne, bogate $\mathrm{w}$ konkretne przykłady $\mathrm{z}$ własnego życia, akcentuje się w nich przeżyte wydarzenia, autorki szczegółowo opisują swój stan psychiczny. Wojna w świetle tych narracji rysuje się jako powszechna tragedia, która to jednak autorki dotknęła najbardziej. Wizja świata oraz pojmowanie czasu są całkowicie uzależnione od życia rodzinnego kobiet - teksty ukazują obrazy dzieci półsierot i rolę, którą teraz odgrywa ich matka-karmicielka. Roli tej kobiety te nauczyły się podczas mobilizacji mężów, ale jednak się z nią do końca nie pogodziły.

Znalazłszy się w sytuacji bez wyjścia, wdowy zwracały się do wyższego sowieckich urzędników jako „opiekunów” i „obrońców”. Pytały, dokąd lepiej się przeprowadzić po ukończeniu wojny, żeby zorganizować swój byt i dać dzieciom wykształcenie. Paradoksalne jest to (i jest to typowe dla państwa totalitarnego), że wyższe kierownictwo jawi się jako zdepersonalizowane, a teksty są pełne zwrotów do osób, ale anonimowych: „usilnie proszę Pana Przewodniczącego, by Pan mi pomógł”, „proszę Pana o zezwolenie na przyjazd do Lwowa”, „usilnie proszę Pana, Panie Przewodniczący”50. W tego rodzaju listach najlepiej zarysowuje się obraz amorficznego, a jednocześnie wszechmogącego funkcjonariusza sowieckiego, który rozstrzyga ludzkie losy. Do osób na wysokich stanowiskach ludzie pragnęli dotrzeć osobiście, dlatego wysyłając list polecony np. do Rady Komisarzy Ludowych w Kijowie, na kopercie oraz w liście

\footnotetext{
47 Cyt. za: Н. Козлов а, op. cit., s. 52.

48 О. Стяжкіна, op. cit., s. 75.

49 ДАЛО, ф. Р-6, оп. 2, спр. 22, k. 60.

50 Ibidem, k. 45-45v.
} 
dopisywano adnotację, że podanie jest skierowane bezpośrednio do przewodniczącego, którego nazwiska raczej nie znano i wcale go poznać nie chciano.

W tekstach mężczyzn, których wśród odrzuconych listów było dużo mniej, odczuwalny jest bardziej swobodny, a nieraz nawet ostry styl wypowiedzi. Pisano: „czy mogę jak najszybciej dostać wyczerpującą odpowiedź w sprawie poruszonej kwestii”, „z góry dziękuję i pozdrawiam” ${ }^{51}$. Pewność siebie, dążenie do celu, nieugiętość są właściwe listom kobiet, które zajmowały kierownicze stanowiska, były wybierane na radne rady obwodowej. Zakończenia listów autorstwa takich kobiet są zgodne $\mathrm{z}$ duchem czasu i podobne do typowo męskich wypowiedzi: „Drogi towarzyszu przewodniczący bardzo proszę o udzielenie zezwolenia na wjazd do miasta Lwowa... Z komsomolskim pozdrowieniem, Nata Reutowa" ${ }^{2}$.

Typowe dla kobiecych tekstów są formy bierne: „proszę o wydanie rozporządzenia o wysłanie mnie... do ojczyzny..., skąd byłam ewakuowana”, „nie byłam przez nikogo ewakuowana”, „proszę o skierowanie mnie do pracy do miasta Lwowa”"53. Jednak z powodu załamania nerwowego wdowy łamały ustalone standardy typowo „męskich” i „kobiecych” zwrotów i pisały bardzo natarczywie w celu osiągnięcia swojego celu. W liście do zastępcy przewodniczącego Rady Komisarzy Ludowych ZSRS Wiaczesława Mołotowa wdowa zastępcy dowódcy pułku, która zamieszkała na jakimś chutorze (nazwa nie została podana w liście) po reewakuacji z Gruzji, zwracała się bardzo stanowczo, przymuszając swojego adresata do pomyślnego rozpatrzenia sprawy:

Postanowiłam zwrócić się do Pana w bardzo ważnej sprawie życia i śmierci, w której Pan musi [podkreślenie - H.B.] mi pomóc. Pan jest naszym urzędem, pełnym sprawiedliwości i mądrości... Moja prośba dotyczy następującego: proszę mi pomóc, proszę doradzić, dokąd się udać po ukończeniu wojny, by mieć możliwość utrzymywać się i wychowywać dzieci... Gdzie tacy jak ja, prowadzący cygańskie życie, nie mający własnego kąta i męża, mogą odnaleźć jakieś schronienie ${ }^{54}$.

Typowe dla listów jest bezwarunkowe oddanie i deklarowana wierność władzy sowieckiej. Teksty te są wręcz przesiąknięte tego typu postawami. Najlepszym przykładem jest podkreślanie przez wdowy długoletniej służby zmarłego męża w wojsku oraz wyliczanie zajmowanych przez niego stanowisk: „zastępca dowódcy pułku”, „komisarz brygadowy" i in. Jedna $z$ wdów w swoim podaniu powoływała się na list od swojego męża z frontu, który dowodził jego oddania Związkowi Sowieckiemu:

Na łożu śmierci mój mąż pisał: „Trzeba żyć krótkim, ale jaskrawym życiem, jeśli mi przyjdzie oddać życie za nasz naród, za Ojczyznę, bez strachu oddam życie za wyzwolenie

${ }^{51}$ Ibidem, k. 69-69v: Заява Мхітарьяна Сергія Семеновича до голови облвиконкому м. Львова, м. Сухумі Абхазької АРСР (тепер Грузія), 15 VIII 1945.

${ }_{52}$ Ibidem, k. $127-127 \mathrm{v}$.

53 Ibidem, k. 41: Заява Іванської Ємілії Дмитрівни до Президії Верховної ради УРСР, Краснодарський край Росії, 5 VIII 1945; k. 142: Заява дружини загиблого бригадного командира Ковальової Варвари Федосівни, Смоленська обл. Росії, 1945.

${ }^{54}$ Ibidem, k. 104-104v. 
od ludożerców naszych dzieci i matek. Nas nie zapomną, a tobie udzielą pomocy, nie będziesz sama, trzymaj się, pogódź się z myślą, że bez ofiar nie ma wojny”. Był to bolszewik o rzadkim umyśle i bolszewik o gorącym sercu, wyśmienity agitator i propagandysta... ${ }^{55}$

\section{Wyobrażenia Lwowa}

W listach wdów sowieckich wojskowych do władz miasta Lwów jawi się przede wszystkim jako miasto, w którym znajduje się własne mieszkanie. Porzucone w wyniku ataku Niemiec w czerwcu 1941 r. mieszkania kobiety niezaprzeczalnie uważały za swoją własność. Świadczą o tym następujące zwroty: „mieszkanie i majątek pozostały we Lwowie”, „moje mieszkanie i majątek”, „moje mieszkanie jest wolne, są też meble”, „posiadam informacje, że moje mieszkanie jest całe i częściowo zachował się mój majątek” itd. Wspominając ewakuację ze Lwowa, kobiety często pisały: „Wszystko pozostało tam...”. Powrót do Lwowa jawił się jako „życiowo ważna kwestia” także dla osób pochodzących spoza Ukrainy Zachodniej. Wspominając Lwów, niemiejscowi zawsze podkreślali, że jest to miasto - „г. Львов”, „гор. Львов”. Niektórzy nie orientowali się co do geograficznego położenia miasta, dlatego zdarzało się im lokować Lwów na Białorusi Zachodniej ${ }^{56}$.

W listach mieszkańców różnych zakątków Związku Sowieckiego Lwów często wydawał się komfortowym miejscem do osiedlenia ze względu na wolne mieszkania, miejsca pracy oraz lepszy klimat - który również był jednym z argumentów podawanych jako uzasadnienie konieczności przeprowadzki. W listach pisano np. o zaleceniach od lekarza, by „zmienić klimat”, złym samopoczuciu w obecnym miejscu zamieszkania i naturalnie o braku środków do życia. O zezwolenie na migrację do Lwowa $\mathrm{z}$ powodu chorujących dzieci ubiegały się zarówno osoby, które były ewakuowane ze Lwowa, jak i te, które nigdy nie były na Ukrainie Zachodniej. Jedna z wnioskodawczyń pisała o śmierć wskutek malarii swojej młodszej córki w Baku i dlatego prosiła o ratunek dla starszej córki poprzez umożliwienie przyjazdu do Lwowa. By udowodnić swoje kwalifikacje zawodowe mające umożliwić podjęcie pracy w nowym miejscu zamieszkania, dołączyła do podań także kopie uzyskanych dyplomów. Aby z kolei potwierdzić trudną sytuację materialną - list Oddziału Rady Komisarzy Ludowych Azerbejdżańskiej Republiki Ludowej ds. Zakwaterowania i Zatrudnienia Ewakuowanej Ludności. Lwów jako oczekiwane miejsce przeprowadzki podawano także ze względu na perspektywy edukacyjne potomstwa. Zdaniem wielu matek dzieci w starszym wieku miasto to dawało lepsze możliwości zdobycia przez nie wykształcenia wyższego (w porównaniu z możliwościami, jakie istniały np. w Uzbekistanie) ${ }^{57}$.

Z opracowanych listów wyłania się obraz Lwowa jako miasta „wyzwolonego”. Wśród młodszych kobiet (urodzonych w latach 20. XX. w.) pojawiał się argument

${ }^{55}$ Ibidem, k. 123: Лист Квактун Євгенії Аронівни до керівника Відділу скарг виконкому Львівської міської ради А. Любімової, 1945.

${ }^{56}$ Ibidem, k. 32-32v, 36.

${ }^{57}$ Ibidem, k. 45-45v. 
chęci przyjazdu do Lwowa, by tam pracować i „odbudowywać miasto”. Lwów to dająca perspektywy „miejscowość przemysłowa” ${ }^{2}$.

Pojawienie się w listach informacji o zajmowanych stanowiskach czy miejscach pracy świadczy o postępujących zmianach $\mathrm{w}$ świadomości. Nina Cwietajewa pisała: „Uświadomienie sobie własnej wagi za pomocą oficjalnych kryteriów ideologicznych jest nową znaczeniową strukturą człowieka w społeczeństwie porewolucyjnym, która, jak pokazują teksty biograficzne napisane dziesiątki lat później, z biegiem czasu utrwala się na tyle, że może zastępować inne wartości życiowe" ${ }^{59}$. Autorki listów pisały o swoim zawodzie i kwalifikacjach, a niektóre podkreślały, że nie mają represjonowanych krewnych, że są członkami Komsomołu, są narodowości rosyjskiej ${ }^{60}$, dlatego prosiły o zapewnienie „niedużej powierzchni mieszkalnej”. W takich listach zauważalne jest przekonanie, że Lwów to miasto, w którym są wolne mieszkania, dlatego można tam delegować autorki listów do pracy ${ }^{61}$. Przeprowadzkę do Lwowa postrzegano też jako możliwość otrzymania pracy w swoim zawodzie, ponieważ po ewakuacji trzeba było pracować "gdzie się dało”.

W oczekiwaniu na demobilizację do Lwowa pragnęli się również przeprowadzić żołnierze armii sowieckiej, żeby móc „jak najszybciej się urządzič”. Latem 1945 r. Lwów jawi się jako miasto o „mieszkaniowych i bytowych możliwościach”, gdzie można bez problemów znaleźć pracę i dostać mieszkanie ${ }^{62}$. We Lwowie chcieli zamieszkać także ci, którzy już odbyli kilka przeprowadzek. Na przykład kobiety ze Stalingradu najpierw przeniosły się do Chorołu w obwodzie połtawskim, po czym w sierpniu 1945 r. na poważnie zastanawiały się się nad koniecznością „urządzenia się i znalezienia pracy" ${ }^{63}$. Zwracały się z prośbą o jak najszybsze wystawienie zezwoleń, by zdążyć przeprowadzić rodzinę $\mathrm{z}$ ewakuacji przed początkiem zimy.

Lwów kusił też pogłoskami o tanich artykułach spożywczych i dostępie do innych towarów. Pewien inwalida wojenny pisał:

Jako obrońca Leningradu chcę poprawić stan swojego zdrowia, dlatego mój wybór padł na Lwów, ponieważ tam żyje się prościej i taniej, lwowski klimat również bardziej mi pasuje. Jestem inwalidą drugiej grupy, dostaje rentę o wysokości 225 rubli. Jest to bardzo mało, ponieważ żywność w Dnipropetrowsku jest bardzo droga, na przykład wiadro ziemniaków kosztuje 160 rubli. Posiadam informacje, iż we Lwowie ziemniaki są dziesięć razy tańsze, już nie mówiąc o innej żywności ${ }^{64}$.

${ }^{58}$ Ibidem, k. 151-151v: Заява Митрофанової Тетяни Семенівни і Костикової Анастасії Семенівни до голови виконкому Львівської міської ради, 10 VIII 1945.

${ }_{59}$ Н. Цв е та ев а, Советский биограбический дискурс..., s. 116.

${ }^{60}$ ДАЛО, ф. Р-6, оп. 2, спр. 22, k. 62.

${ }^{61}$ Ibidem, k. 146: Заява Житкової Ольги Макарівни голові виконкому Львівської міської ради, VIII 1945.

${ }_{62}$ Ibidem, k. 89-90: Лист Максімовича Петра Ілліча до голови Львівської міської ради, до мобілізації жителя м. Мінськ Білорусі, Польова пошта, 2 VIII 1945.

${ }^{63}$ Ibidem, k. 151-151v: Заява Митрофанової Тетяни Семенівни і Костикової Анастасії Семенівни до голови виконкому Львівської міської ради, 10 VIII 1945.

${ }^{64}$ Ibidem, k. 212: Заява Горбачова Євгенія Степановича до голови Урядової комісії, м. Дніпропетровськ. 
Tylko w jednym liście Lwów jawił się jako miasto „drogie”. Jego autorka przeprowadziła się już do Lwowa wraz z rodziną jednej z córek, teraz zaś starała się o sprowadzenie drugiej - z Archangielska. Mężowie córek autorki listu stracili życie w trakcie wojny (jeden z zięciów został zabity przez banderowców w rejonie sokalskim w obwodzie lwowskim), stąd połączenie rodziny kobieta traktowała jako konieczność. Swoją prośbę do władz miasta Lwowa o zgodę na przyjęcie jej drugiej córki argumentowała jednak swoją własną trudną sytuacją materialną. Pisała, że córka „przywiezie nam rzeczy, które pozostawiliśmy po przeprowadzce do Lwowa oraz może nam pomóc finansowo" ${ }^{2}$. Prawdę mówiąc, argument o drożyźnie mógł zostać użyty, aby przekonać urzędnika o tym, że przybycie córki jest autentycznie niezbędne dla dalszego funkcjonowania rodziny.

Lwów zachowywał renomę miasta nieosiągalnego. Części wnioskodawców nie udawało się trafić do Lwowa, mogli natomiast osiedlić się np. pod Kijowem lub Czernihowem. W 1945 r. żonie, której mąż już mieszkał we Lwowie, nie udzielano powtórnego zaproszenia po tym, jak zgubiła oryginał wydany we wrześniu/październiku $1944 \mathrm{r}$. W okresie ponad półrocznego oczekiwania wnioskodawczyni zdążyła przeprowadzić się z Kraju Krasnodarskiego w Rosji do obwodu kijowskiego i następnie planowała swoją przeprowadzkę do Lwowa ${ }^{66}$. Wdowa po komisarzu brygadowym w odpowiedzi na swój wniosek o zezwolenie na zamieszkanie w obwodzie czernihowskim otrzymała zezwolenie na przyjazd do Czernihowa w lipcu 1945 r., ale już w sierpniu tego samego roku wnosiła o przeprowadzkę do Lwowa do mieszkania przydzielonego jej mężowi w latach 1939-1941 ${ }^{67}$.

W poszczególnych listach wdów ewakuowanych na Wschód Lwów jawił się nie jako cel, a raczej jako jedna z niezłych perspektyw do przeprowadzki, by otrzymać mieszkanie i inne możliwości, które stwarzało życie w tym mieście (tak samo jak np. Kijów $)^{68}$.

\section{Zakończenie}

Listy zawierające prośby o udzielenie zezwolenia na przeprowadzkę do Lwowa pokazują obraz powojennego zasiedlania miasta przez migrantów z Rosji, wschodniej i południowej Ukrainy, innych republik Związku Sowieckiego, a w razie udzielania odmów - jak w przypadku wdów po sowieckich wojskowych, które już tu mieszkały w latach 1939-1941 - obraz potencjalnych lwowian, którym jednak nie udało się takowymi zostać. Jednak wypowiedzi autobiograficzne, w które bogate są takie listy, są wartością same w sobie, ponieważ są to unikatowe egodokumenty czasów II wojny światowej, stworzone przez same kobiety i pozwalające na zrozumienie ich życia po

${ }^{65}$ Ibidem, k. 174: Заява від Лєбєдєвої Уляни Митрофанівни до голови виконкому Львівської міської ради, м. Львів, 9 IV 1945.

${ }^{66}$ Ibidem, k. 67: Заява Ємєлянової Р. С., м. Шпола Київської обл., 16 VIII 1945.

67 Ibidem, k. 83: Відповідь начальника секретаріату НКВС УРСР на запит Ковальової Варвари Федосіївни, 17 VII 1945.

${ }^{68}$ Ibidem, k. 104-104v. 
ewakuacji, pragnień powrotu do Lwowa, sposobów przekonywania do swoich racji funkcjonariuszy sowieckich, w których ręku znalazł się ich przyszły los.

Żony sowieckich wojskowych zajmujących wysokie stanowiska w armii były przyzwyczajone do stabilnych zarobków, przewidzianych przez państwo ulg i przywilejów oraz mało dbały o zapewnienie warunków życia swoich rodzin. Wojna bardzo odmieniła ich sytuację. Życie po ewakuacji skutek inwazji niemieckiej w czerwcu 1941 r. stało się wydarzeniem przełomowym dla każdej kobiety, która musiała teraz zostać głową rodziny i walczyć o przetrwanie i wyżywienie. Pogodziwszy się ze śmiercią męża na froncie, wdowy po sowieckich wojskowych nie chciały się jednak pogodzić z pogorszeniem się swojego położenia w hierarchii społecznej ZSRS po II wojnie światowej. Kobiety chwytały się tego, co im pozostało - chciały przywrócić sobie przedwojenne mieszkania, które według prawa ZSRS po śmierci męża już do nich nie należały, a co za tym idzie - wrócić do Lwowa, „miasta wyzwolonego” o szerokich możliwościach znalezienia pracy w zawodzie, dobrymi perspektywami edukacyjnymi dla dzieci i lepszych (niż na Wschodzie) warunkach klimatycznych. Teksty listów ponadto wyraźnie pokazują opanowanie przez kobiety tzw. „języka sowieckiego” i zdolność kreowania się na ofiarę, choć paradoksalnie - by urzec urzędnika - niekiedy podkreślano te atuty, który czyniły z autorki przykład „kobiety walczącej”, łamiąc tym samym utarte standardy tekstów kobiecych.

\section{s) \\ Bibliografia}

\section{Źródła archiwalne:}

Державний архів Львівської області (ДАЛО):

ф. Р-6: Виконавчий комітет Львівської міської ради депутатів трудящих, оп. 2, спр. 10-19: Заяви і відношення громадян і установ на видачу дозволу на в’їзд в м. Львів, 10 томів, 12 IX - 30 XII 1944.

спр. 22: Листи громадян, надіслані з інших міст з проханням вислати дозвіл на в’їзд в м. Львів, 26 XII 1944 - 20 VII 1945.

спр. 43: Заяви військовослужбовців про дозвіл на в’їзд в м. Львів, 26 X - 22 XII 1944. спр. 45: Документи перевірок скарг трудящих (постанови, акти, листування), 19 IX - 29 XII 1944.

спр. 103-147: Заяви і відношення громадян і установ на видачу дозволу на в’їзд в м. Львів, 45 томів, 1945.

спр. 149: Листи громадян, надіслані з інших міст 3 проханням на в’ізд в м. Львів, 28 VI - 4 X 1945 та ін.

\section{Opracowania:}

Allport G., Letters from Jenny, New York 1965.

Боднар Г., Львів. Щоденне життя міста очима переселенців із сіл (50-80-ті роки $X X$ cm.), Львів 2010. 
Боднар Г., Жити в омріяному місті. Заяви-прохання повоєнних мешканщів Львова про дозвіл на переїзд родини (1944-1945 роки), „Вісник Львівського університету. Серія історична" [w druku].

Боднар Г., Житло як тягар і привілей. до питання про способи радянізаиії Львова y другій половині 1940-х років, [w:] Lwów. Miasto, społeczeństwo, kultura. Studia z dziejów Lwowa, t. 9: Życie codzienne miasta, red. K. Karolczak, Ł. T. Sroka, Kraków 2014, s. 413-443.

Вилєгала А., Росіяни і російськомовне населення в сучасному Львові, [w:] Нове суспільство в давньому місті. Пам'ять та історична політика засобами оral history, вид. Л. Генке, Г. Россолінський, Ф. Тер, Вроцлав 2007, s. 237-256.

Вронська Т., Заручники тоталітарного режиму. Репресії проти родин „ворогів народу” в Україні (1917-1953 рр.), Київ 2009.

Козлова Н., Советские люди. Сиены из истории, Москва 2005.

Коляструк О., Документи особового походження як джерела з історії повсякденності, „Український історичний журнал” 2008, вип. 2, s. 145-153.

Макарчук С., Евакуація поляків зі Львова у 1944-1946 pp., [w:] Lwów. Miasto, społeczeństwo, kultura. Studia z dziejów miasta, t. 4, red. K. Karolczak, Kraków 2002, s. 401-411.

Сартр Ж.-П., Идиот в семье. Гюстав Флобер от 1821 до 1857, Санкт-Петербург 1998.

Семенова В., Качественные методы. Введение в гуманистическую соиіологію, Москва 1998.

Стяжкіна О., Володарі часу. Чому радянське (не)завериується, [w:] Радянськість. Спроба діагностики крізь призму повсякденності. 3б. матеріалів II Всеукр. наук-теорет. семінару, 7-8 квітня м. Вінниия, відп. ред. О. Коляструк, Вінниця 2017, s. 63-89.

Сусак В., Етнічні та соціальні зміни в населенні Львова в 1939-1999 роках. Магістерська робота. Львівський національний університет ім. І. Франка, Львів 2000.

Терлюк І., Росіяни західних областей України (1944-1996 рр.). (Етносочіальне дослідження), Львів 1997.

Тош Д., Стремление к истине. Как овладеть мастерством историка, Москва 2000.

Фукс-Хайнритц В., Биографический метод, [w:] Биографический метод. История, методология, практика, ред. кол. Е. Мещеркина, В. Семенова, Москва 1994, s. 11-41.

Цветаева Н., Биографические нарративы советской епохи, „Социологический журнал” 2000, № 1/2, s. 162-176.

Цветаева Н., Советский биографический дискурс, „Социологический журнал” 1999, № 1/2, s. 111-125.

Галина Боднар, Війна в одній долі. Біографічні наративи вдів радянських військовослужбовців за листами до влади міста Львова 1944-1945 років

У статті проаналізовано листи-прохання вдів радянських військовослужбовців другої половини 1944-1945 років до влади міста Львова про дозвіл на переїзд/повернення, конструювання жінками біографічних наративів і образу жінки у війні. У повоєнній кореспонденції йшлося про випробування війною і різні долі жінок зі спільним 
досвідом життя у Львові в 1939-1941 роках, схожі стратегії виживання і комунікації з тоталітарною державою, суперечливе окреслення власного образу жінки у війні. Особиста драма загибелі чоловіка, різке падіння соціальною ієрархією і, зокрема, позбавлення “довоєнного” житла у Львові й решту можливостей життя у великому місті спонукали жінку в уже почасти опанованій ролі голови родини шукати способи повернути собі втрачені позиції, серед маси доволі схожих звернень до влади привернути увагу до себе. Наративний аналіз листів дозволив виокремити образи Львова в уявленнях людей (по)воєнного часу, розкрити “радянську мову” і (не)типові гендерні аспекти жіночих текстів.

Ключові слова: вдови радянських військовослужбовців, Львів, 1944-1945 рр., листи-прохання, житлове питання, біографічний наратив, наративний аналіз

\section{Halyna Bodnar, The War in One Fate: Biographical Narratives of Widows of Soviet Ser- vicemen on the Basis of Letters to the Authorities of Lviv in 1944-1945}

The article analyzes letters written in late 1944 and in 1945 by widows of Soviet servicemen to the authorities of the city of Lviv requesting a permit to move or return to Lviv, the construction of women's biographical narratives and the image of women in the war. The main topic discussed in post-war correspondence was the war trials and different fates of women sharing the experience of life in Lviv in 1939 -1941. It demonstrates similar strategies of survival and communication with the totalitarian state, and the contradictory image of woman in war time. The personal drama of her husband's death, the sudden collapse of the social hierarchy, and, in particular, the destruction of "pre-war" housing stock in Lviv and other livelihood opportunities in a big city, prompted woman, in the already partly assumed role of the head of the family, to look for ways to regain their former position. Probably, they wrote special letters, among many other quite similar appeals to the government, in order to attract attention to themselves. The narrative analysis of the letters has made it possible to isolate the images of Lviv in the representations of people of the (post)war period, to disclose the „Soviet language” and the (un)typical gender-related aspects of texts written by women.

Keywords: widows of Soviet Servicemen, Lviv, late 1944 and 1945, letters of request, housing question, biographical narrative, narrative analysis 